Vol. 24, No. 1, Januari 2021, hlm. 38-46

p-ISSN: 1410-9344; e-ISSN: 2549-5631

WARTA LPM

homepage: http://journals.ums.ac.id/index.php/warta

\title{
Pelatihan Software bagi Komunitas Jurnalisme Warga Semarang
}

\author{
${ }^{1}$ Taruna Budiono, ${ }^{2}$ Agus Triyono \\ Program Studi Penyiaran, Universitas Dian Nuswantoro Semarang \\ Email : ${ }^{1}$ tarunabudiono@gmail.com, ${ }^{2}$ agustriyono7@gmail.com
}

\section{Article Info}

Submitted: 04 March 2020

Revised: 30 April 2020

Accepted: 09 May 2020

Published: 12 December 2020

Keywords : Citizen Journalism, software, news

Kata kunci : Jurnalisme Warga, software, berita

Abstract

Citizen Journalism, has become an inseparable part of the current journalistic activities. Events that are usually rarely covered by the mainstream media can now reach the public through Citizen Journalism channels. The development of Citizen Journalism in Indonesia is arguably encouraging, this is marked by the large number of people who share information in various forms, from writing to video through social media. But this is not without problems, the dissemination of information by the public on social media is generally still in the form of fragments of events that are not intact, so prone to cause misunderstanding when consumed by the public. This is because the jurnalis wargas do not have the ability to organize news coherently, or in the case of video news they do not have software skills. The solution to these problems is to held software training for Citizen Journalism activists. This community service activity involves the Semarang Citizen Journalism community as trainees. The results of this training will be a news video with a maximum duration of 2 minutes, which will be uploaded through the Youtube channel citezen journalism Semarang community. With this training, activists of Citizen Journalism, especially in the city of Semarang have been able to do news editing so that it becomes a coherent entity so that the news produced meets journalistic rules.

Abstrak
Jurnalisme warga telah menjadi bagian tidak terpisahkan dari kegiatan
jurnalistik sekarang ini. Peristiwa-peristiwa yang biasanya jarang
diliput oleh media mainstream sekarang bisa sampai ke masyarakat
melalui saluran jurnalisme warga. Perkembangan jurnalisme warga
di Indonesia dapat dikatakan menggembirakan yang ditandai
dengan banyaknya masyarakat yang membagikan informasi dalam
berbagai bentuk, mulai tulisan hingga video melalui media-media
sosial. Namun hal ini bukan tanpa masalah, penyebaran informasi
oleh masyarakat di media sosial umumnya masih berupa potongan-
potongan peristiwa yang tidak utuh, sehingga rawan menimbulkan


kesalahpahaman ketika dikonsumsi oleh khalayak. Hal ini disebabkan karena para jurnalis warga tersebut tidak memiliki kemampuan untuk menyusun berita secara runtut, atau dalam hal berita video mereka tidak memiliki keahlian editing video. Solusi dari permasalahan tersebut adalah dengan mengadakan pelatihan software bagi para penggiat jurnalisme warga. Kegiatan pengabdian ini melibatkan komunitas jurnalisme warga Semarang sebagai peserta pelatihan. Hasil dari pelatihan ini adalah video berita dengan durasi maksimal 2 menit, yang akan diunggah melalui channel Youtube komunitas citizen journalism Semarang. Dengan pelatihan ini, penggiat jurnalisme warga, khususnya di kota Semarang telah mampu untuk melakukan editing berita sehingga menjadi suatu kesatuan yang runtut sehingga berita yang dihasilkan memenuhi kaidah jurnalistik.

\section{PENDAHULUAN}

Jurnalisme warga atau Jurnalisme Warga telah menjadi bagian integral dari kegiatan jurnalistik. Citizen Jounalism juga disebut sebagai Participatory Journalism menekankan pada partisipasi warga negara dan masyarakat umum sebagai pelaku kegiatan jurnalistik. Hasil dari kegiatan Jurnalisme Warga ini sangat beragam, dari tulisan di media sosial, sampai video yang ditayangkan di segmen khusus di televisi yang mengakomodasi hasil kerja jurnalisme warga. Effendy (2003) menjelaskan, kegiatan jurnalistik sebagai teknik mengelola berita mulai dari mendapatkan bahan sampai kepada menyebarkannya kepada masyarakat. Dalam konteks jurnalisme warga ini, maka yang bertindak sebagai pelaku kegiatan jurnalistik adalah warga masyarakat.

Jurnalisme warga yang di media mainstream sering diartikan dengan berita yang dikirim oleh warga yang tidak memiliki latar belakang pendidikan jurnalistik atau bukan sebagai jurnalis profesional, tidak sama dengan istilah jurnalisme publik. Jurnalisme publik atau civic journalism adalah sebuah gaya jurnalistik yang dikembangakan oleh wartawan profesional di Amerika Serikat untuk menyikapi ketidakpercayaan publik terhadap media mainstream. Meskipun demikian, civic journalism ini yang membuka celah bagi tumbuhnya Jurnalisme Warga atau jurnalisme warga yang kita kenal sekarang. Berita sendiri, menurut Charnley dan James M. Neal adalah laporan tentang suatu peristiwa, opini, kecenderungan, situasi, kondisi, interpretasi yang penting, menarik, masih baru dan harus secepatnya disampaikan kepada khalayak (Alwi, 2000).

Jurnalisme warga atau Jurnalisme Warga adalah bentuk khusus dari media warga dan user generated content (UGC). Dengan menyandingkan istilah "warga negara", dengan "jurnalisme", yang mengacu pada profesi tertentu. Istilah jurnalisme warga sendiri paling tepat digunakan untuk menggambarkan bentuk khusus jurnalisme online dan jurnalisme digital yang dilakukan oleh amatir, karena menggarisbawahi hubungan antara praktik jurnalisme dan hubungannya dengan ruang politik dan publik (Radsch, 2012).

Perkembangan Jurnalisme Warga di Indonesia bisa dibilang menggembirakan, karena memungkinkan masyarakat Indonesia memiliki akses untuk menjadi subyek dalam pemberitaan. Masyarakat juga mendapat kesempatan menyuarakan aspirasinya karena memiliki space di online media. Hal ini penting mengingat media massa, meski berada di dalam lingkup negara yang memiliki kebebasan pers, tetap memiliki keterbatasan misalnya kecondongan pada berbagai kepentingan terutama kapital dan politis. Dengan demikian maka penting untuk menyambut Jurnalisme Warga yang diharapkan akan memberikan warna tersendiri yang lebih independen dan jujur di dunia media di Indonesia.

Jurnalisme Warga menarik perhatian masyarakat karena media mainstream seringkali tidak kreatif dalam menyampaikan berita. Dalam riset yang dilakukan oleh Tamara Witschge tentang jurnalisme warga, ia menyebutkan bahwa banyak jurnalis professional terjebak 
dalam kultur administratif yang mengharuskan jurnalis untuk terikat dengan meja kerja mereka yang mengakibatkan berita yang dihasilkan adalah hasil daur ulang dari materi-materi yang sudah ada sebelumnya dibandingkan dengan mencari kisah baru yang menarik untuk diangkat menjadi berita (Witschge, 2009).

Web, bagi banyak orang, telah menjadi identik dengan Internet. Penggunaan Web telah ada di mana-mana, dari warnet, hostel, hingga intranet perusahaan dengan bandwidth tinggi. Tetapi adopsi universal browser web sebagai antarmuka pengguna, bagi banyak orang, telah menutupi fakta bahwa Internet menyediakan jalinan komunikasi (Austerberry, 2005). Jalur komunikasi yang disediakan oleh Internet ini bisa digunakan untuk menyampaikan informasi dalam berbagai bentuk, salah satunya dalam bentuk video streaming. Kanal-kanal video streaming sekarang ini semakin berkembang dengan hadirnya Youtube sebagai media sosial yang menyediakan platform onlien video streaming.

Kemudahan akses internet dan berkembangnya media sosial dengan fitur streaming video seperti facebook atau Youtube yang menjadi platform khusus online video streaming di Indonesia juga turut membuat jurnalisme warga makin marak. Kegiatan ini bahkan tidak hanya sebatas menyajikan berita secara tertulis, namun juga dalam bentuk audio visual seperti berita televisi. Beberapa stasiun televisi nasional bahkan memiliki program khusus untuk mengakomodasi kegiatan jurnalisme warga ini. Lebih jauh lagi, penetrasi internet yang semakin dalam di masyarakat Indonesia membuat warga masyarakat memiliki lebih banyak pilihan media dalam mengakses berita, begitu juga dengan warga penggiat jurnalisme warga, mereka memiliki banyak pilihan media yang bisa digunakan untuk menyebarkan informasi yang mereka dapat, baik berupa tulisan, foto, maupun video. Youtube sendiri memiliki kategori channel News \& Politics (Fahs, 2008) untuk mengakomodir kegiatan jurnalisme warga di platform tersebut.

Berita televisi menurut JB Wahyudi adalah laporan tentang peristiwa atau pendapat yang memiliki nilai penting, menarik bagi sebagian khalayak, masih baru dan dipublikasikan secara luas melalui media massa periodik (Wahyudi,
2007). Kekuatan berita televisi terletak pada gambar. Konsekuensinya, crew televisi yaitu reporter dan cameraman harus bekerja sama saat berada di lokasi kejadian ketika meliput suatu peristiwa (Badjuri, 2010). Di lokasi kejadian tugas reporter adalah mengumpulkan data untuk dituangkan kedalam naskah berita, sementara juru kamera mengambil gambar di lokasi, dan mengambil gambar narasumber ketika reporter melakukan wawancara. Hal ini tidak mungkin dilakukan oleh warga ketika meliput suatu peristiwa, karena mereka tidak memiliki sumber daya yang memadai seperti crew televisi. Keterbatasan ini menjadikan produk jurnalisme warga hanya berupa video amatir yang tidak memenuhi kaidah jurnalistik.

Selain televisi, media sosial sekarang ini juga menjadi media favorit untuk warga dalam mengabarkan suatu peristiwa. Fitur-fitur di berbagai media sosial yang memungkinkan penggunanya melakukan unggahan video, dimanfaatkan oleh pengguna untuk melakukan kegiatan jurnalisme warga. Meskipun demikian unggahan tersebut hanya berupa video amatir tanpa dilakukan editing yang memadai untuk membangun suatu narasi berita utuh yang bisa dipahami oleh audience.

Istilah editing sendiri mencakup banyak kemungkinan dalam produksi video. Editor video sederhana bekerja dalam dua cara dasar, dengan merangkai atau dengan memasukkan bagian-bagian materi atau klip yang terdiri dari sejumlah frame untuk membuat karya sampai selesai (Watkinson, 2008). Editing sendiri adalah sebuah proses manipulasi rekaman video untuk menghasilkan presentasi final untuk disajikan kepada penonton (Sadun, 2003). Proses editing dapat dibagi menjadi dua tahap: (1) tahap merakit gambar menjadi potongan kasar dan (2) tahap di mana editor dan sutradara menyempurnakan atau memperhalus potongan kasar, mengubahnya menjadi potongan yg lebih tertata. Pada tahap akhir, ritme dan aksentuasi bisa ditambahkan (Dancyger, 2007).

Kendala yang dihadapi oleh para jurnalis warga ini adalah tidak adanya skill atau kemampuan software yang mereka kuasai. Hal ini membuat video yang mereka unggah ke media sosial tidak memiliki nilai jurnalistik serta tidak mudah dipahami oleh penonton 
berita. Berbeda dengan wartawan yang dibekali dengan ilmu jurnalistik dalam melakukan pekerjaannya, warga disini melakukan kegiatan jurnalistik tanpa bekal keilmuan sama sekali. Hal ini menjadi masalah ketika produk jurnalistik tersebut disampaikan kepada khalayak. Dalam kasus jurnalisme warga yang berbentuk video amatir, pesan yang disampaikan oleh jurnalis warga rentan tidak dipahami oleh penonton secara baik, karena ketidakmampuan jurnalis warga untuk membangun narasi yang mudah dipahami oleh penonton berita.

Hasil video dari jurnalisme warga biasanya hanya berupa video amatir tanpa ada upaya untuk menjadikan video tersebut sebagai sebuah berita yang utuh. Hal ini diperparah dengan masifnya penggunaan media sosial dalam penyebaran video-video amatir hasil rekaman warga, tanpa disertai dengan informasi yang relevan tentang suatu peristiwa yang ada dalam video. Dengan demikian, selain pesan yang sulit dipahami oleh penonton, tidak lengkapnya informasi yang beredar ke masyarakat melalui video amatir tersebut rentan menjadi sumber hoax atau berita bohong. Untuk menghindari hal itu, serta untuk menambah kemampuan para jurnalis warga dalam memproduksi berita dalam bentuk video, maka dibutuhkan solusi untuk permasalahan tersebut.

Di kota Semarang, ada komunitas warga yang gemar melakukan kegiatan jurnalisme warga dan menyebarkan hasil kerja mereka melalui media sosial mereka masing-masing. Output dari kegiatan mereka beragam mulai dari tulisan di media sosial, sampai video yang mereka unggah di akun masing-masing. Anggota komunitas ini yang aktif ada 25 orang, yang berdomisili di Kota Semarang dan Kabupaten Semarang (Ungaran, dan Bawen). Komunitas ini telah aktif melakukan kegiatan jurnalisme warga sejak tahun 2019. Anggota komunitas ini menggunakan gawai berupa ponsel dan kamera digital untuk melalukan liputan suatu peristiwa. Meskipun mereka sudah mahir menggunakan gawai berupa ponsel dan kamera digital, namun ada kendala yang membuat video hasil liputan mereka tidak memiliki nilai berita yang utuh.

Kendala yang mereka hadapi selama ini adalah ketidakmampuan mereka dalam mengolah dan menyusun video yang telah direkam menjadi satu bentuk video berita yang utuh. Karenanya video yang mereka unggah kebanyakan hanya video amatir tanpa memenuhi kaidah jurnalistik. Selain itu, video yang mereka unggah di media sosial tidak memiliki narasi, dan tanpa keterangan narasumber. Solusi yang ditawarkan untuk menyelesaikan permasalahan mitra adalah sebagai berikut : Mengadakan pelatihan software bagi komunitas jurnalisme warga, denga target luaran berupa satu buah video berita berdurasi maksimal 2 menit untuk setiap peserta pelatihan.

\section{METODE}

Rencana kegiatan yang akan dilakukan dalam pengabdian masyarakat ini yaitu: sosialisasi, pelatihan, dan workshop secara terstruktur terhadap berbagai hal yang menjadi kendala dalam upaya meningkatkan kemampuan para anggota komunitas jurnalisme warga dalam bidang software.

Kegiatan pengabdian masyarakat ini dilakukan dengan cara : pertama menghubungi mitra pengabdian masyarakat dan mendiskusikan permasalahan yang mereka hadapi dalam hal pengolahan dan editing video, serta program apa yang bisa dilakukan untuk mengatasi persoalan tersebut. Kedua, merencanakan jadwal pengambilan gambar bagi peserta pelatihan yang belum memiliki bahan berupa video mentah / footage untuk editing. Ketiga, melakukan pengumpulan footage yang akan dipakai oleh peserta pelatihan untuk dilakukan editing. Keempat, melaksanakan pelatihan software bagi Komunitas Jurnalisme Warga Semarang, yang dilaksanakan di Laboratorium Multimedia Universitas Dian Nuswantoro Semarang pada tanggal 6-7 Januari 2020.

Mitra dalam kegiatan pengabdian ini adalah Komunitas Jurnalisme Warga Semarang, mereka adalah komunitas yang biasa mengunggah hasil kerja jurnalistik mereka melalui media sosial masing-masing. Produk jurnalistik mereka beragam, mulai dari tulisan, foto, dan video yang diunggah melalui media sosial seperti facebook, instagram, dan youtube. Sasaran dari program pengabdian ini adalah produk Komunitas Jurnalisme Warga Semarang yang berbentuk video. Metode pelaksanaan program pengabdian ini digambarkan melalui diagram alir pelaksanaan kegiatan pengabdian sebagai berikut :

Warta LPM, Vol. 24, No. 1, Januari 2021 


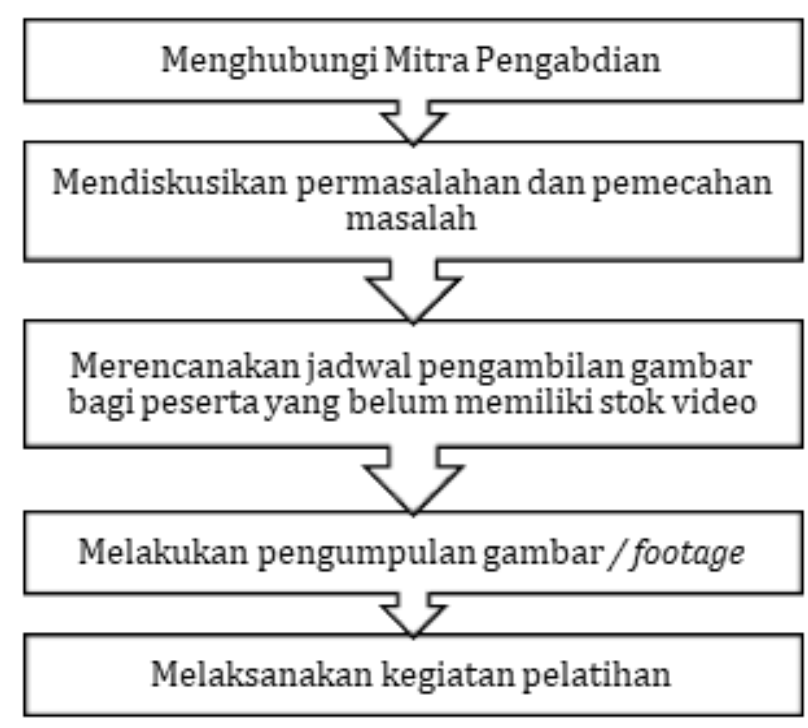

Bagan 1. Diagram alir pelaksanaan kegiatan

Pelaksanaan program diawali dengan pengumpulan footage dari setiap peserta pelatihan, selanjutnya footage tersebut dicopy ke komputer masing-masing peserta pelatihan. Setelah itu peserta pelatihan mulai dikenalkan dengan software editing yang akan digunakan yaitu Adobe Premiere Pro CS6, serta diberikan materi tentang dasar-dasar software. Adobe Premiere Pro dipilih sebagai software editing yang dipakai untuk pelatihan karena pertimbangan sebagai berikut 1) Adobe Premiere Pro bisa menerima berbagai format file video mengingat gawai yang dipakai oleh peserta pelatihan beragam, mulai dari ponsel sampai kamera digital berbagai merk. 2) Adobe Premiere pro memiliki keunggulan dalam hal export video di mana software ini mampu menghasilkan video dengan berbagai macam format sesuai kebutuhan peserta pelatihan. Dan 3) Adobe Premiere Pro adalah software software professional yang tingkat kesulitannya moderat, dengan tampilan antar muka yang relatif mudah dipahami oleh pemula sekalipun.

Pemilihan software editing Adobe Premiere Pro ini juga didasarkan dari kemampuan peserta pelatihan yang beragam, diantara peserta ada beberapa yang sudah pernah mengoperasikan software editing sebelumnya, namun sebagian besar peserta masih awam dengan software editing video berbasis komputer desktop. Mengingat hal tersebut, maka materi pertama yang diberikan kepada peserta pelatihan adalah tentang dasar-dasar software. Materi ini diberikan untuk membangun pemahaman mereka tentang software.

Setelah peserta pelatihan memahami dasar-dasar software, peserta diminta untuk melakukan editing footage yang telah mereka serahkan sebelumnya, dengan ketentuan peserta melakukan editing video dengan hasil akhir video berdurasi maksimal 2 menit. Video yang telah diedit oleh peserta pelatihan software, selanjutnya akan diunggah melalui akun Youtube dengan nama Komunitas Jurnalisme Warga Semarang, yang akan dibuat setelah semua peserta pelatihan menyelesaikan proses pelatihan editing video.

\section{HASIL DAN PEMBAHASAN}

\section{A. Hasil}

Sejak awal perencanaan dan penyususnan proposal program pengabdian masyarakat ini telah melibatkan mitra guna mengetahui secara pasti masalah yang dihadapi, sehingga selama kegiatan pengabdian masyarakat berlangsung dapat berjalan lancar dan tanpa kendala yang berarti. Publikasi kegiatan pengabdian masyarakat dilakukan menggunakan media Youtube, melalui channel Komunitas Jurnalisme Warga Semarang. Akun tersebut dibuat setelah peserta menyelesaikan semua materi pelatihan editing yang diberikan oleh fasilitator.

Video hasil editing peserta diupload ke channel Youtube, dan link dari masing-masing video dibagikan/ di-share oleh peserta melalui sosial media masing-masing. Hasil dari share link video tersebut dipantau selama 3 hari sejak video diunggah ke Youtube dan akan dilihat berapa banyak penonton yang menonton video hasil editing para peserta. Hasilnya video yang ditonton oleh peserta ditonton rata-rata $10 \mathrm{kali}$ sejak pertama kali dilakukan upload ke Youtube. 


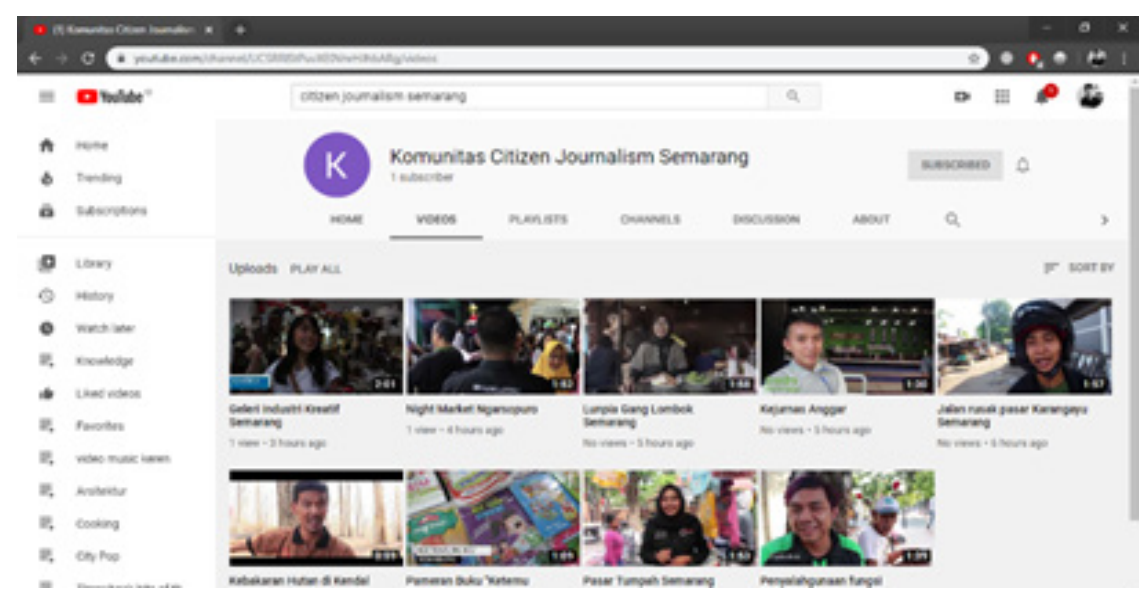

Gambar 1 : Channel Youtube Komunitas Jurnalisme Warga Semarang

\section{B. Pembahasan}

Pada tanggal 6-7 Januari 2020, kegiatan pelatihan software bagi komunitas Jurnalisme Warga semarang dilaksanakan di laboratorium multimedia Universitas Dian Nuswantoro Semarang. Pelatihan dimulai pukul 10.00 sampai dengan 15.00 WIB. Jalannya pelatihan software ini bisa dideskripsikan sebagai berikut. Kegiatan pelatihan software ini dimulai dengan pembukaan dan perkenalan fasilitator dan peserta, pembukaan acara ini dilakukan oleh Dr. Agus Triyono, beliau menjelaskan kepada para peserta pelatihan tentang latar belakang kegiatan, tujuan kegiatan, target kegiatan, dan alur pelatihan yang harus diikuti oleh peserta. Setelah penjelasan tentang alur pelatihan, peserta diberikan kesempatan untuk memperkenalkan diri.

Setelah seluruh peserta memperkenalkan diri, kegiatan dilanjutkan dengan materi tentang jurnalistik online yang disampaikan oleh Dr. Agur Triyono. Dalam materi ini peserta diajarkan tentang bagaimana merangkai sebuah berita di media online agar runtut dan dapat dipahami oleh khalayak pembaca atau dalam hal ini penonton berita. Para peserta juga diajarkan untuk menganalisis dan mengkonfirmasi tentang kebenaran suatu peristiwa sebelum menyebarkan melalui kegiatan jurnalisme warga di media sosial masing-masing. Materi jurnalistik online ini disampaikan sebagai pembuka sebagai jembatan agar peserta pelatihan dapat menghasilkan suatu produk video yang memiliki nilai berita dan dapat dipahami khalayak penonton.

Selanjutnya, kegiatan pelatihan software bagi komunitas jurnalisme warga dilanjutkan dengan sesi pemaparan tentang materi basic editing, dan news editing oleh fasilitator yaitu Taruna Budiono, S.I.Kom., M.I.Kom. Materi basic editing yang disampaikan meliputi tentang dasardasar software, penegenalan software editing, serta materi tentang bagaimana melakukan news editing. Kegiatan pelatihan software kemudian dilanjutkan dengan sesi workshop, dengan mekanisme workshop sebagai berikut. Fasilitator mempersilahkan peserta pelatihan untuk menuju komputer yang telah disediakan oleh fasilitator di laboratorium multimedia Universitas Dian Nuswantoro. Setelah itu para peserta akan diajarkan untuk menyusun footage menjadi sebuah sebuah berita yang utuh lengkap dengan narasi, keterangan tempat, dan keterangan narasumber.

\begin{tabular}{|c|}
\hline Membuat Project editing baru \\
\hline Import Media : Footage dan Voice Over \\
\hline $\begin{array}{c}\text { Menyusun Footage secara runtut di timeline } \\
\text { editing }\end{array}$ \\
\hline Menyusun voice over di timeline editing \\
\hline Titling \\
\hline Melakukan exportvideo sesuai format yang \\
dibutuhkan
\end{tabular}

Bagan 2 : Alur proses kerja pelatihan software bagi komunitas Jurnalisme Warga Semarang 
Langkah pertama yang dilakukan oleh peserta pelatihan adalah membuat folder di komputer masing-masing yang nantinya akan berisi bahan-bahan, dan file project editing yang dibutuhkan. Folder ini penting untuk dibuat karena dengan system folder, file bahan editing dan projectediting akan lebih mudah diorganisasi. Langkah selanjutnya yang dilakukan oleh peserta pelatihan adalah membuat project editing baru menggunakan software Adobe Premiere Pro CS6. Project ini nantinya akan menjadi tempat untuk peserta melakukan proses editing berita. Dalam proses pembuatan project, peserta diajarkan untuk mengetahui dan memilih parameter apa saja yang diperlukan untuk membuat satu project editing, misalnya seperti berapa ukuran video yang akan dilakukan editing, di mana tempat project akan disimpan, dan format file apa yang bias diedit menggunakan software Adobe Premiere Pro CS6. Untuk mempermudah proses dan kegiatan selama pelatihan, peserta diarahkan untuk membuat project editing sesuai dengan file footage yang mereka miliki, artinya setiap peserta akan memiliki spesifikasi project editing yang berbeda, sesuai kebutuhan mereka.

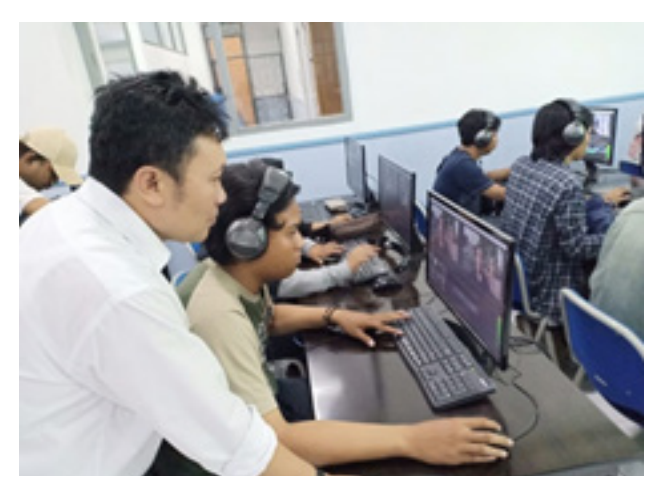

Gambar 2 : Fasilitator sedang memberi arahan pada peserta pelatihan

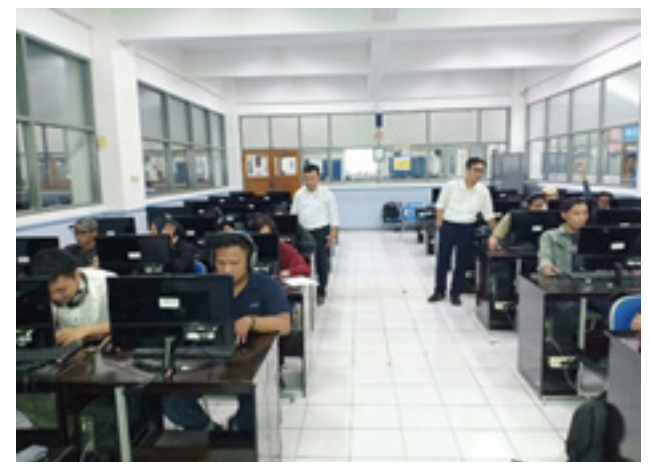

Gambar 3 : Suasana pelatihan software
Langkah selanjutnya setelah peserta berhasil membuat project editing adalah melakukan import media yang terdiri dari footage, musik, dan voice over ke dalam software editing. Import media bisa dilakukan dengan dua cara ; pertama dengan menggunakan menu import yang ada di dalam software Adobe Premiere Pro CS6, langkah kedua yaitu dengan cara drag and drop melalui windows explorer di komputer masing-masing peserta. Setelah semua media yang dibutuhkan untuk proses editing selesai di-import ke dalam software editing, langkah selanjutnya adalah menyusun footage ke timeline editing. Footage atau gambar mentah mulai dimasukan ke timeline editing untuk selanjutnya dilakukan editing. Editing ini meliputi memotong, menyambung, memindah, dan memberi transisi pada gambar.

Proses editing yang dilakukan pada footage tersebut dimaksudkan agar gambar-gambar yang diambil oleh jurnalis warga dapat disusun dengan runtut dan menghasilkan suatu nilai berita, sehingga pesan yang disampaikan menjadi mudah dipahami oleh penonton berita. Setelah footage disususn secara runtut dari awal sampai akhir, langkah selanjutnya yang harus dilakukan oleh peserta pelatihan adalah menyusun voice over di timeline editing. Voice Over atau biasa disebut VO, adalah rekaman suara yang berisi narasi tentang suatu kejadian yang diliput dalam berita. Pada pelatihan ini, peserta telah diminta untuk menyiapkan VO mereka masing-masing untuk dipakai pada waktu editing.

Voice Over dimasukkan ke timeline editing disesuaikan dengan gambar yang telah diedit sebelumnya oleh para peserta pelatihan. Pada saat menyusun VO ini, peserta pelatihan juga melakukan pemotongan dan penyambungan VO sesuai kebutuhan masing-masing. Menyusun VO di timeline bermanfaat untuk peserta pelatihan dalam hal melatih ketepatan dan kecocokan antara gambar dan suara yang akan muncul di berita yang mereka produksi. Sebagai contoh, berita tentang kota lama Semarang, maka VO yang disusun di timeline editing juga mengenai kota lama Semarang.

Dalam pelatihan ini para peserta disarankan telah menyiapkan file VO yang akan dipakai ketika editing berlangsung. Namun ada beberapa peserta yang belum melakukan perekaman 
VO sampai waktu pelatihan, untuk mengatasi hal ini fasilitator menyarankan peserta untuk melakukan perekaman VO dengan menggunakan telepon genggam masing-masing di ruangan yang tidak terlalu berisik. Ruangan yang dipakai adalah ruang laboratorium multimedia D.2.K Universitas Dian Nuswantoro Semarang.

Penyusunan VO di timeline editing, bisa dilakukan diawal yaitu sebelum peserta menyusun footage di timeline editing, atau bisa dilakukan setelah peserta meyusun footage secara runtut di timeline editing. Kedua cara ini bisa dilakukan bergantung pada preferensi atau kenyamanan setiap editor video.

Langkah berikutnya setelah menyusun VO di timeline editing adalah membuat Lower Third dan titling. Lower Third adalag grafis yang terdapat di bagian sepertiga bawah video, yang biasanya digunakan untuk meletakkan nama narasumber yang diwawancara atau reporter saat melakukan stand up di depan kamera. Peserta pelatihan diberikan dasar untuk membuat lower third, selebihnya bentuk lower third dibebaskan sesuai keinginan peserta pelatihan. Selain lower third yang digunakan sebagai tempat tulisan / title pada video, peserta pelatihan juga diajarkan membuat title. Mereka diajarkan untuk memilih font, menulis title, dan menempatkannya sesuai dengan grafis lower third yang telah dibuat. Proses ini bisa dilakukan secara manual atau memanfaatkan template template yang telah tersedia di software editing.

Langkah-langkah editing diatas diakhiri dengan proses exporting video sesuai formatyang dibutuhkan oleh peserta pelatihan. Exporting file adalah langkah akhir yang dilakukan untuk menyatukan semua file footage, voice over, musik, title dan file lainnya yang telah disusun di dalam timeline editing menjadi satu kesatuan file utuh

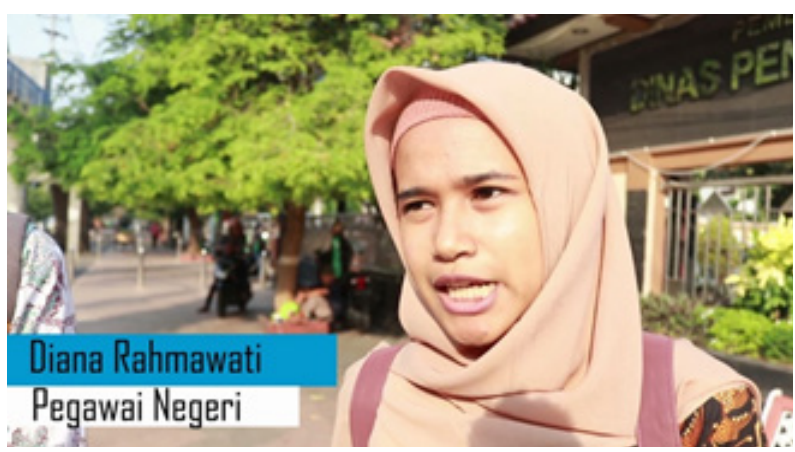

Gambar 4 : Contoh Lower Third dan Titling

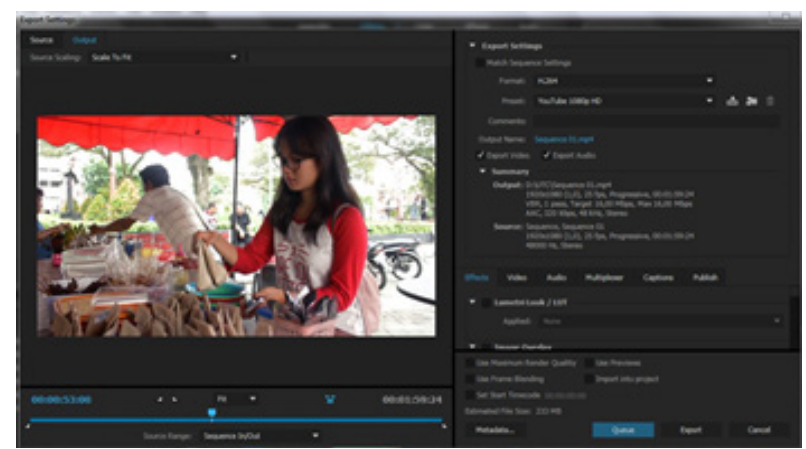

Gambar 5 : Proses export video

yang nantinya bisa diputar di berbagai perangkat pemutar video. Dalam pelatihan ini, karena output video yang dihasilkan akan ditayangkan di media Youtube, maka peserta pelatihan perlu melakukan pengaturan pada saat melakukan exporting file sesuai dengan persyaratan file yang dapat diupload ke Youtube.

Melalui proses pelatihan software ini, manfaat yang diperoleh oleh peserta pelatihan adalah mereka mampu memahami bagaimana menyajikan video berita secara runtut agar dapat dinikmati dan dipahami oleh penonton berita. Selain itu, para peserta pelatihan juga mendapat manfaat praktis mengenai teknik editing video menggunakan software dengan standart industri media. Manfaat lanjutan dari program pengabdian masyarakat ini adalah peserta pelatihan mendapatkan ilmu tentang software yang nantinya bisa mereka aplikasikan untuk keperluan lain selain mengedit video berita.

Secara umum, pelaksanaan program pengabdian masyarakat berupa pelatihan software bagi Komunitas Jurnalisme Warga Semarang ini berlangsung dengan lancar. Kendala-kendala kecil seperti ada beberapa peserta pelatihan yang sama sekali belum pernah menggunakan software editing video, dapat diselesaikan dengan baik karena fasiltator memberikan perhatian khusus bagi para peserta yang belum pernah menggunakan softfware software dengan cara mengujinkan para peserta ini untuk bertanya, dan akan dijawab secara personal dan diberikan pengarah per individu peserta. Sedangkan bagi peserta lain yang sudah pernah menggunakan software software tidak ada kendala berartti, para peserta umumnya cepat memahami penjelasan fasilitator. 
Tabel 1 : Perbedaan kondisi sebelum dan sesudah kegiatan pengabdian masyarakat

\begin{tabular}{lll}
\hline \multirow{2}{*}{ Kegiatan } & \multicolumn{2}{c}{ Kondisi } \\
\cline { 3 - 3 } \cline { 3 - 3 } $\begin{array}{ll}\text { Pemberian materi tentang } \\
\text { basic editing }\end{array}$ & Peserta belum mengetahui & \multicolumn{1}{c}{ Sesudah } \\
Pelatihan software & dasar-dasar software & tentang dasar-dasar software \\
& $\begin{array}{l}\text { Peserta belum bisa melakukan } \\
\text { editing video secara runtut dan }\end{array}$ & $\begin{array}{l}\text { Peserta dapat melakukan } \text { editing } \\
\text { video sesuai kaidah } \text { editing, dan }\end{array}$ \\
& benar & dapat melakukan news editing \\
\hline
\end{tabular}

\section{SIMPULAN}

Program pengabdian ini telah berhasil dilaksanakan dengan baik, dengan indikasi telah tercapainya target dari program pengabdian ini, yaitu peserta pelatihan memiliki pengetahuan tentang dasar-dasar software, dan dapat melakukan editing video sesuai kaidah editing, dan dapat melakukan news editing. Kerjasama yang baik dengan mitra pengabdian telah menjadikan program ini berjalan dengan baik dan sukses.

Saran bagi program pengabdian sejenis di masa mendatang adalah dengan melakukan proses produksi berita dari tahap pra produksi hingga pasca produksi, sehingga peserta pelatihan dapat memahami keseluruhan proses produksi berita yang benar mulai tahap awal yaitu pra produksi, sampai tahap akhir yaitu pasca produksi, atau dalam hal ini tahap editing.

\section{UCAPAN TERIMA KASIH}

Program pengabdian ini dapat terlaksana dengan baik atas kerjasama dengan Komunitas Jurnalisme Warga Semarang, yang telah bersedia menjadi peserta pelatihan. Program ini juga terlaksana atas kerjasama dengan laboratorium multimedia Universitas Dian Nuswantoro Semarang sebagai penyedia tempat pelaksanaan pelatihan.

\section{DAFTAR PUSTAKA}

Alwi, A. M. (2000). Foto Jurnalistik. Bumi Aksara.

Austerberry, D. (2005). The Technology of Video and Audio Streaming (2nd ed.). Elsevier.

Badjuri, A. (2010). Jurnalistik Televisi. Graha Ilmu.

Dancyger, K. (2007). The Technique of Film and Software (4th ed.). Elsevier.

Effendy, O. U. (2003). Ilmu, Teori dan Filsafat Komunikasi. PT. Remaja Rosdakarya.

Fahs, C. (2008). How to do Everything with YouTube. McGraw-Hill.

Radsch, C. \& K. D. K. (2012). Adapting Concepts of Media Freedom to a Changing Media Environment: Incorporating New Media and Citizen Journalism into the Freedom of the Press Index. ESSACHESS Journal for Communication Studies, 5(1).

Sadun, E. (2003). Digital Video Essentials : Shoot, Transfer, Edit, Share. Sybex.

Wahyudi, J. B. (2007). Dasar-Dasar Jurnalistik Radio dan Televisi. Pustaka Utama Grafiti.

Watkinson, J. (2008). The Art of Digital Video. Elsevier.

Witschge, T. (2009). Street Journalists versus "Ailing Journalists"? http://www.opendemocracy.net/ article/street-journalists-as-an-answer-to-ailing-journalism 